\title{
The Aims and Discussions of the Foundation of Land Reform in Estonia After the WWI ${ }^{1}$
}

\author{
Dr. iur. Marju Luts-Sootak \\ Faculty of Law, University of Tartu \\ Professor of Legal History \\ E-mail: marju.luts-sootak@ut.ee \\ MA Karin Visnapuu \\ Law School, University of Tartu \\ PhD candidate \\ E-mail: karin.visnapuu@ut.ee
}

\begin{abstract}
The land reform was one of the most important tasks of independent Estonia after World War I. The groundwork started even before gaining its independence which shows the significance of this extensive reform. Similar reforms were carried out in other Eastern- and Middle-European countries after World War l, but the Estonian land reform was considered to be among the most radical ones at that time period. The decisions about the scope, intensity and the radicality of a reform would influence the later outcome, therefore it is important to understand the legislative discussions in the beginning and during the reform. In the article we will examine the legislative discussions of Estonian Constituent Assembly and Parliament about the expropriation of largescale estates in Estonia, the legal solutions and, consequently, the reasons why the question about compensation and redistribution of the expropriated land was left unregulated in the Land Reform Act.
\end{abstract}

Keywords: Republic of Estonia, Land Reform Act 1919, Constitution 1920, parliamentary discussions.

\section{Contents}

Introduction .................................. 112

1. The Economic Situation at the Beginning of the Republic of Estonia and the Purpose of the Land Reform . . . . . . . . . . . . . . . . . . 113

2. The Constitutional Order and the Legal Foundation of the Land Reform . . . . . . . . . 115

3. Expropriation of Land . . . . . . . . . . . . . . . . . . . . . . . . 117

4. The Question on Compensation for Expropriated Land . . . . . . . . . . . . . . . . . 119

Summary. . . . . . . . . . . . . . . . . . . . . . . . . . . . . . . . . . . 125

Sources . . . . . . . . . . . . . . . . . . . . . . . . . . . . . . 125

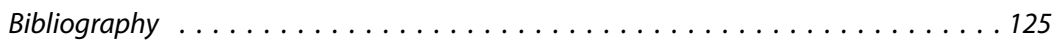

Normative Acts . . . . . . . . . . . . . . . . . . . . . . . . . . . 127

Other Sources . . . . . . . . . . . . . . . . . . . . . . . . . . . . . . . . . . 127

1 The research for this article has been supported by Estonian Research Council (PRG969). 


\section{Introduction}

The current year, 2021, marks the $30^{\text {th }}$ anniversary of the land reform, whereby the Republic of Estonia, after regaining independence on 20 August 1991, sought to rearrange the institutions of Soviet agriculture: exclusive state ownership of land, large-scale agricultural production in state-owned or quasi-cooperative enterprises, central planning and absence of free market. Estonia chose the route of reprivatisation to return the land to private ownership. The beneficiaries of the process were the former owners or legal holders of the land nationalised during the Soviet era, or their descendants. The reform mainly dealt with small-scale land ownership, as this was the dominant agrarian structure in Estonia by 1940, when the Soviet Union occupied and annexed the Republic of Estonia. The agrarian structure predominantly based on small-scale ownership was substantially different from the conditions in the Republic of Estonia at its beginning in 1918-19, when large-scale land ownership also dominated, albeit the ownership was mostly held by Baltic German estate owners, necessitating a comprehensive land reform to rearrange the agrarian conditions.

The land reform of Estonian Republic between the two World Wars is considered to be one of the most radical ones ${ }^{2}$ - all the former large-scale estates were expropriated all at once and initially without paying any compensation whatsoever. This was done by adopting the Land Reform $\mathrm{Act}^{3}$, which was supposed to form the basis of the land reform in Estonia. Still, the Land Reform Act itself left some fundamental issues unsolved. ${ }^{4}$ The two key topics, which needed to be decided, were to what extent should the large-scale holdings be expropriated (and should there be any compensation for the expropriation), and to what extent and under which conditions should the land be redistributed. In this article, we will focus on the first key topic and examine the reasons, why some of these fundamental topics were left unregulated in Land Reform Act and its implementation act. At the outset, we examine the causes and aims of Estonian land reform (1). Subsequently, we demonstrate the crucial significance of the land reform for the internal consolidation and security of an independent Estonian statehood (2). The next chapter views the crucial discussions in the Constituent Assembly about the expropriation of the land from estate owners (3) and the last chapter concerns the discussions in the Constituent Assembly, continued later in the parliament, as to whether a compensation for the expropriated land would be determined or not.

As land reforms took place in several Central and Eastern European countries during the same period, both contemporary and modern literature has been published on the Estonian land reform alone, as well as in comparison with the land reforms that took place in other European countries. ${ }^{5}$ One of the purposes of this

2 In contrary to the contemporary "land reforms" in other European states, the reforms in Estonia, as well as in Latvia were called "agrarian revolutions". Cf. Korfes, O. Die Agrarrevolutionen in Estland und Lettland. In: Sering, M. (Hg.). Die agrarischen Umwälzungen im außerrussischen Osteuropa. Berlin, Lepizig 1930, S. 72-127; Jörgensen, H. The Inter-War Land Reforms in Estonia, Finland and Bulgaria: A Comparative Study. Scandinavian Economic History Review, Vol. 54, Issue 1, 2006, p. 87.

3 State Gazette, No. 79/80, 1919.

4 The question whether to compensate the previous large-scale estates was left unregulated, the same as the question on what legal basis the land would be redistributed.

5 In foreign languages, e.g., Gert von Pistohlkors. Tiefgreifende agrarische Umwälzungen und Umstrukturierungen in den neu gegründeten baltischen Staaten Estland, Lettland und Litauen 1919/1920/1922: Motivationen und Ergebnisse bis 1940. Krauss, K. P. (Hg.). Agrarreformen und ethnodemographische Veränderungen. Südosteuropa vom ausgehenden 18. Jh. bis in die Gegenwart. 
article is to show the discussions in Estonian legislative bodies and to introduce the material found in Estonian language literature and archive sources to an international audience.

\section{The Economic Situation at the Beginning of the Republic of Estonia and the Purpose of the Land Reform}

The land reform that took place in Estonia after World War I was neither the first nor last in the Estonian territory. Estonian historians consider the first land reform to have been the agrarian reform of the early $19^{\text {th }}$ century, which established the ownership of farmlands by the estate owners and the duty of estate labour by the peasants. The second land reform took place in the middle of the $19^{\text {th }}$ century, which lead to the beginning of selling land by the estate owners to farmers in addition to tenure. ${ }^{6}$ The process of separating farmsteads from the estates and selling them to peasants started in the 1860s in Southern Estonia and reached Northern Estonia a couple of decades later. ${ }^{7}$ Despite that, large-scale holdings still made up $58 \%$ of agricultural land in 1919. ${ }^{8}$ This meant a total of 2428087 hectares of 1149 estates with an average area of 2113 hectares. Many estate owners owned more than one estate, making their total land assets even greater. $23 \%$ of the estates had been leased to peasants for use under tenure with the average farmer leasing a plot of land of 24.2 hectares. Around a third of the tenants, however, had less than 10 hectares of land. By that time, $42 \%$ of the agricultural land in the whole of Estonia was in private ownership by farmers. The average size of a farmstead bought by the farmers was 34.1 hectares, although about a quarter of the farms encompassed less than 10 hectares. Such small farmsteads were often not sufficient for feeding a family. ${ }^{9}$

As such, one of the most important objectives of the land reform was to guarantee the chances to obtain sustenance for as large a part of the Estonian populace as possible. This concerned those who did not have any land to cultivate at all. The former tenants were also meant to gain confidence that they could continue farming the land in their use and possibly become its owners in the future.

Stuttgart, 2009, S. 175-2006; Jörgensen, H. The Inter-War Land Reforms in Estonia, Finland and Bulgaria, pp. 64-97; Kõll, A.-M. The Agrarian Question in Eastern Europe: Some Answers from the Baltic Region. In: David, T., Batou, J. (eds.). Uneven Development in Europe 1918-1939. Librarie Droz, 1999, pp. 201-229; Roszkowski, W. Land Reforms in East Central Europe after World War One. Warsaw, 1995; Lipping, I. Land Reform Legislation in Estonia and the Disestablishment of the Baltic German Rural Elite 1919-1930. Dissertation, University of Maryland Faculty of the Graduate School. Michigan, London, 1980; Uluots, J. Grundzüge der Agrargeschichte Estlands. Tartu, 1935; Bernmann, O. Die Agrarfrage in Estland. Berlin, 1920; Luiga, G. E. Die Agrarreform in Eesti. Helsinki, 1920.

6 Nõu, J. Eesti põllumajanduse omariiklusaegne koetus ja arengutase [The structure and level of development of Estonian agriculture during the period of independence]. In: Omariikluse taustal. Üliõpilasselts Raimla koguteos [In the context of independence. Collected works by Student Society Raimla]. Uppsala, 1955, pp. 59-70.

7 A good overview of the process of purchasing farmsteads with an impressive array of sources has been given in: Laur, M., Lust, K., Pirsko, P., Tarkiainen, Ü. Talude päriseksostmine Pärnumaa andmestiku põhjal [The purchasing of farmsteads on the basis of data from Pärnumaa]. Tartu, 2014, pp. 9-14.

8 Rosenberg, T. Maaküsimus ja 1919. aasta maareform Eestis: põhjused, eeldused ja tulemused [The land question and the land reform of 1919 in Estonia: reasons, preconditions and results] (first published in 1994). In: Rosenberg, T. Künnivaod. Uurimusi Eesti 18.-20. sajandi agraarajaloost [Ploughed fields. Inquiries on the agrarian history of Estonia in the $18^{\text {th }}$ to $20^{\text {th }}$ century]. Tartu, 2013, p. 374 .

9 Pool, T. Maauuendus Eestis ja selle tulemusi [Land reform in Estonia and its results]. In: Fenno-Ugrica V. Soome-ugri kultuurkongress (ettekanded) [Finno-Ugric cultural congress (lectures)]. Tallinn, 1936, pp. 4-8; Virma, F. Maasuhted ja maakorraldus Eestis [Land relations and land arrangement in Estonia]. Tartu, 2004, p. 118. 
The land reform was not just a rearrangement of agrarian conditions, but also a necessary step in solidifying the constitutional order of the democratic Republic of Estonia. Theodor Pool (1890-1942), an agronomist and a politician, has been considered the "father" of the land reform..$^{10} \mathrm{He}$ argued that breaking up the estates eliminated the economic foundation of the nobility, which was hostile to the newly created republic, and prevented the threat of (German) colonisation. In addition to the former small farmers, it also created a new class of independent farmers who were connected to Estonian independence, forming a strong support and backbone of the young country. ${ }^{11}$

In the legislative discussions in the Constituent Assembly, the land reform was also regarded as solidifying the independence of Estonia. During a debate over the Land Reform Act, Karl Ast (1886-1971), a member of the Social Democratic Party, said: "The Estonian land reform, however, is most closely connected to Estonian independence". The land reform was also seen as a means of ameliorating centurieslong injustice. Prime Minister Otto Strandman (1875-1941) of the Labour Party remarked in a session of the Constituent Assembly on the estate owners' land possessions: "This power must be taken from them and given to the people". Ast seconded him: "The time has come in Estonia, when the historical injustice, which has greatly impeded our spiritual and imperial development, is beginning to be ameliorated". Aleksander Veiler (1897-19590), another member of the Labour Party also emphasized the historical injustice: "Not just in the sense of making good the historical injustice, but also in the sense of ensuring our national independence, must we eliminate large-scale land ownership. [..] Estonian independence can surely never preserve, if land is to remain in possession of the nobles who are the fiercest enemies of our independence." 12

The thousands of beneficiaries of the land reform were supposed to become loyal citizens of the Republic of Estonia. As Johannes Lehtmann (1886-1953) of the Labour Party said in a late-night session of the Assembly on 1 August 1919: "We must especially emphasize this economic moment, because the Land Reform Act is the lever with which our independence will be pulled up. We cannot execute our independence without deciding the question of land."13

In addition to the political purpose emphasized by the left-wing parties, the so-called bourgeoisie parties introduced purely economic considerations into the debate. A few months earlier, during a session of the Committee on the Land Reform Act on 1 May 1919, Jaan Tõnisson (1868-1941?), leader of the People's Party, emphasized that the political motive of the reform (mollifying the people and ensuring their loyalty) should not force anyone to neglect to pay attention to

10 Karelson, M. Theodor Pool Eesti Vabariigi põllumajanduses [Theodor Pool in the agriculture of the Republic of Estonia]. Tartu, 2000; Karelson, M. Theodor Pool - maaseadus ja maareform [Theodor Pool - the Land Reform Act and land reform]. In: Agraarteadus (Akadeemilise Põllumajanduse Seltsi Toimetused 13) [Agrarian Science (Publications of the Academic Aricultural Society 13)]. Tartu, 2000, pp. 10-15.

11 Pool, T. Maauuendus Eestis ... [Land reform ...], p. 9.

12 Asutawa Kogu protokoll 29.07.1919 [Minutes of the Constituent Assembly 27 July 1919], No. 40. In: Asutawa Kogu II istungjärk: protokollid nr. 28-97 (17. juuni - 20. dets. 1919. a) [II session of the Constituent Assembly: minutes No. 28-97 (17 June 1919 - 20 December 1919)]. Tallinn, 1920, col. 433, 441, 444-446, 452.

13 Asutawa Kogu protokoll 01.08.1919 [Minutes of the Constituent Assembly 1 August 1919], No. 41. In: Asutawa Kogu II istungjärk: protokollid nr 28-97, col. 537. 
the agricultural viewpoint. Tõnisson called upon the members of the Committee to weigh the matter impartially and without partisanship so as not to hurt the people. ${ }^{14}$

On the other hand, caution was necessary, because backlash from the former landowners was probably inevitable. The same also applied to the owners' farmsteads that had already been purchased. They had received their farmsteads from lands that had been separated by the estate owners during the mid- $19^{\text {th }}$ century agrarian reforms as agriculturally less productive. The lands distributed as a result of the land reform, on the other hand, had been kept by the estate owners for their own households and were more fertile or otherwise better.

The threat of international backlash, which the local nobility was not slow to incite, also necessitated caution. In order to balance the "poetic colours" of the leftwing parties, as Jüri Uluots (1890-1945), a member of the Country People's Union, described at the debates in the Constituent Assembly, he himself considered it necessary to focus on the analysis of the legal provisions of the Land Reform Act. ${ }^{15}$ $\mathrm{He}$ also spoke of Estonian independence, albeit in a somewhat different context. Uluots emphasized that Estonian independence had only the de facto recognition of other countries and international organisations, and it was therefore necessary to be cautious and avoid recklessness in the implementation of the land reform. However, the left-wing parties formed a majority in the Constituent Assembly, and it was largely a consequence of their influence that the decision was made to carry out the land reform in Estonia which was to be one of the most radical among its contemporaries.

\section{The Constitutional Order and the Legal Foundation of the Land Reform}

In 1918, the Manifesto of Independence on 24 February declared Estonia an independent democratic republic. Point 7 of the Manifesto stated: "The Provisional Government shall be tasked with developing the proposals for legislation to solve the questions of land, labour, sustenance and finance according to democratic principles immediately". ${ }^{16}$ As the Constituent Assembly convened on 23 April 1919, its primary task was drafting the Constitution, but solving the land question mentioned in the Manifesto could not be considered any less important. The matter of land reform had already been at the centre of the election campaign of all parties. ${ }^{17}$ The question of land was also more important than the Constitution for the contemporary general public, as not just the local Estonian and German

14 Asutava Kogu maaseaduse komisjoni koosolek 01.05.1919, protokoll nr 2 [Minutes of the Land Reform Act commission of the Constituent Assembly 1 May 1919, No. 2]. Rahvusarhiiv [Estonian National Archive], ERA.15.2.370, p. 3.

15 Asutawa Kogu protokoll 01.08.1919, nr 41 [Minutes of the Constituent Assembly 1 August 1919, No. 41], col. 489-490.

16 State Gazette, No. 1, 1918.

17 Pilve, E. Millele nad lootsid?: Eesti Rahvaerakonna ja Eesti Maarahva Liidu maailmapoliitika ning selle kujunemine 1919. aasta maaseaduse eel [What did they hope for?: World politics of the Estonian People's party and Estonians Country People's Union]. Akadeemia, No. 2, 2017, pp. 239-259, No. 3, 2017, pp. 413-442; Roasto, M. Konstantin Pätsi "maaküsimus" ja selle ajalooline kontekst [The "land question" of Konstantin Päts and its historical context]. Ajalooline ajakiri / The Estonian Historical Journal, No. 4, 2014, pp. 303-328; Roasto, M. The political debate about the land question in the Estonian area of the Baltic provinces, 1905-1914. Journal of Baltic Studies, No. 51(4), 2020, pp. 611-630. 
newspapers ${ }^{18}$, but also the foreign press paid more attention to the Land Reform Act than the Constitution. ${ }^{19}$

Before gaining independence, the territory of Estonia was a part of the Russian Empire which was far from democracy or true parliamentarism and rule of law even after the limited modernisation that followed the revolution of 1905. Meanwhile, the ideals of democracy and rule of law were always at the forefront of the Estonian independence movement. The first thorough Estonian language work on the nature of rule of law was published during the German occupation in 1918. ${ }^{20}$ Although Estonia's Constitution of 1920 did not explicitly mention the term "rule of law" or the concept of Rechtsstaat, the structural elements of the basic principles of rule of law did exist and the contemporary lawyers and public figures repeatedly pointed that out. For example, Ferdinand Karlson (1875-1941), an attorney and public figure, wrote, "Free Estonia is a legal state or at least she has a desire to be that." ${ }^{21}$ In 1937, Eduard Laaman (1888-1941), who was a companion of the authoritarian president Päts and at the time rarely had much good to say about the early days of the Republic, said that the most positive aspect of the Constitution of 1920 was the great influence of lawyers in its development. He argued that the whole public life of the country had thus been built on a foundation of justice and that the legal rationalisation of life had led to a state with a rule of law. ${ }^{22}$

At the beginning of independence, Estonian economy and society were still predominantly agrarian and in this particular field the way of life largely continued to resemble a feudal order. It may be questioned whether all of the so-called landless men really desired their own plot of land, but it is undeniable that "hunger for land" was the crucial factor that shaped Estonian governance and politics. It is important to remember with regard to the land reform that at the time the Republic of Estonia was still fighting a War of Independence to preserve its freedom and sovereignty. The men, who were tired of the Great War, were not exactly eager to return to the battlefield. The poor country, on the other hand, did not have any resources to raise their morale. Thus, it is no wonder that this oft-mentioned hunger for land was to become the driving force that would drive the men to enlist. A decree by the Provisional Government on 20 December 1918 explicitly promised that "all the citizens of Estonia who have demonstrated extraordinary bravery on the frontline against the enemy or been injured in battle, as well as the families of those fallen in action, shall receive land for personal use at no cost." ${ }^{23}$ According to Point 2 of the

18 See the overview in: Mertelsmann, M., Mertelsmann, O. Landreform in Estland 1919. Die Reaktionen von Esten und Deutschbalten. Hamburg, 2012, S. 47-68.

19 E. g. Keyserling, H. von. Esthonia's Future - The Land Question. The Daily Telegraph, 17.09.1919; Leminkainen, Y. [= Hermann von Keyserling]. Die Politische Bedeutung von Estland: Das Verhältnis zum Bolschewismus. Neue Freie Presse (Wien), 08.01.1921, S. 2. It must be noted that it was the Baltic Germans who had lost their land, who turned to the foreign public. Most active ones were Heinrich von Stryk, Alfred von Schilling and Hermann von Keyserling, but also baroness Mary Ann Knorring and others. More about the opposition of the Baltic Germans: Loit, A. Baltisaksa rüütelkondade seisukohad ja tegevus Eesti iseseisvumisel 1918-1920 [The views and activity of the Baltic German knighthood at the independence of Estonia 1918-1920]. Tuna, No. 4, 2006, pp. 60-61, 65-68; Undusk, J. Eesti kui Belgia. Viimane baltlane Hermann Keyserling [Estonia like Belgium. The last Baltic Hermann Keyserling]. Tuna, No. 2, 2003, pp. 59-60, 68-89.

20 Einbund, K. Õiguslik riik [The Rule of Law]. Tartu, 1918.

21 Karlson, F. Õigusteaduse oskussõnad [Terms of law]. Õigus, No. 1, 1920, p. 6.

22 Laaman, E. Isik ja riik Eesti põhiseadustes [Person and state in Estonian constitutions]. Õigus, No. 3, 1937, p. 104.

23 Ajutise Valitsuse määrus [Decree of the Provisional Government] (20.12.1918). State Gazette, No. 9, 1918. Also the $\$ 21$ of the Land Reform Act stated: "the first people to get the land are: 1) citizens 
same decree, they were to be given land from the national land reserves of the state and the National Agriculture Bank even before the question of land had been solved in the Constituent Assembly.

The state did not have enough land of its own to fulfil the promises given during the war. The (mainly Baltic German) estate owners, whose loyalty to the Republic of Estonia was not particularly reliable anyway, ${ }^{24}$ on the other hand, had more than enough land. Already in the $19^{\text {th }}$ century, one of the most important theses of the Estonian national movement had been the narrative that, after conquering the Estonian lands during the crusades, the German nobles had taken the Estonians' land also in the literal sense. In other words, the German right to ownership of land in Estonian territory was not considered justified or lawful anyway. The Baltic German propaganda literature, spread in Germany and elsewhere, depicted the Estonian land reform as a great act of revenge against centuries-long injustice. ${ }^{25}$

\section{Expropriation of Land}

Although the Land Reform Act may have been more important than the Constitution in the eyes of the contemporary people and media, the Constituent Assembly had first and foremost convened with the purpose of drafting the Constitution and establishing a strong legal basis for a democratic Republic of Estonia. Before the Assembly started compiling the final text of the Constitution, a temporary constitution was passed on 4 June 1919 for the period of the Constituent Assembly's session. ${ }^{26}$ Although this act also contained a section on the basic rights of citizens ${ }^{27}$ and was rather noteworthy in that regard ${ }^{28}$, the right to protection of private property was not included in this temporary constitution. This does not mean that the Committee on Constitution of the Constituent Assembly did not discuss the potential inclusion of a clause on protection of private property. This was already included in the preliminary draft by Jüri Uluots, on which the committee based its own work. Uluots thought that the matter of private property

who have showed extreme courage in the War of Independence; 2) soldiers who have been injured in the War of Independence; 3) the families of soldiers who have died in the War of Independence; 4) soldiers who have taken part in combat activities against the enemy taken the length of the activities into consideration”. State Gazette, No. 79/80, 1919.

24 The attempt of the Baltic German to create the so-called United Baltic Duchy (Vereinigtes Baltisches Herzogtum) is quite well-known. Much less known is how the Baltic Germans worked hard to establish and obtain the consents of Estonian and Latvian to merge Estonian and Latvian areas with the German Empire. More about this attempt: Kuldkepp, M. Rahvusliku enesemääramise kaudu Saksamaa külge: eestlased anneksionistliku Saksa poliitika sihtmärgina 1918. aasta okupatsiooni eel [Unification with Germany through national self-determination: Estonians as a target of annexionist German policy before the 1918 German occupation]. In: Tannberg, T. (ed.). Esimene maailmasõda ja Eesti. II [WWI and Estonia. II]. Tartu, 2016, pp. 369-433.

25 Quotations by: Rosenberg, T. Eesti 1919. aasta maareformi historiograafia [Historiography of the Estonian land reform of 1919] (first published in 2002). In: Rosenberg, T. Künnivaod ... [Ploughed fields ...], p. 383.

26 State Gazette, No. 44, 1919, p. 91. Usually in literature about the history of Estonian constitutionalism, this legal act is addressed rather briefly. See more or less all of the relevant references: Vallikivi, $H$. Kodanikuõiguste peatükk Eesti 1919. aasta ajutises põhiseaduses [Civil rights chapter in Estonia’s 1919 Preliminary Constitution]. Ajalooline Ajakiri / The Estonian Historical Journal, No. 3/4, 2019, pp. 294-295.

27 Vallikivi has dedicated his detailed article to the analysis of the development and discussions held over this specific topic. Vallikivi, H. Kodanikuõiguste ... [Civil rights ...], pp. 293-330.

28 Kalmo, H., Luts-Sootak, M. Eesti riik kui kunstiteos [Estonian state as a piece of art]. Sirp, 06.09.2019, p. 12. 
ought to be explicitly stated in the Constitution; it should either be allowed and protected, or outlawed altogether. The Marxist assembly members supported a ban on private property, whereas Uluots himself considered defence of private property necessary as a right to property was also meant to protect the individual. Konstantin Päts (1874-1956) who was Uluots' fellow party member, supported this view as well, albeit he wished to add that expropriation of private property had to remain possible and take place in the interests of the country in accordance with relevant laws. Both of these proposals were rejected by the committee. Uluots raised the matter of private property again in front of the full Assembly, arguing that, as the state was to be granted strong powers to intervene in private enterprise (as demanded by the left-wing majority), a strong defence of the citizens' private property was needed. His new proposal included a clause stating that expropriation of private property was allowed for the greater societal good with adequate legal basis and for a just compensation. Jaan Tõnisson of the People's Party also supported this proposal. The proposal was still rejected by the left-wing majority with the justification that private property was already protected by other laws. ${ }^{29}$

Laaman later explained that the strong opposition by the left-wing parties to free enterprise, as well as private property rights was caused by the specific context of 1919: during the war, it was feared that expanded freedom of enterprise would lead to the growth of speculation, black-market business activities and the reluctance to approve strong protection of private property was caused by the ongoing preparations for the expropriation of large-scale land holdings under the Land Reform Act. ${ }^{30}$

The Committee on the Constitution started compiling the constitution proper in August of 1919. Uluots was once again the author of the preliminary projects. These included a section on protection of private property with all the classical elements: private property was protected, but could be expropriated without the owner's consent if the expropriation took place on a legal basis and for a just compensation. During the first reading in the committee, the draft was amended to restrict the protections of the norm to Estonian citizens, to exclude all property rights' violations except for expropriation from the protections of the draft, and to exclude the right to compensation. An amendment specifying that property could only be expropriated in the interests of the common good was added during the second reading. Uluots tried to reintroduce the requirement for just compensation, but his proposal was rejected. Ado Anderkopp (1894-1941) of the Labour Party explained that the matter of compensation had already been solved in the Land Reform Act and if the right to compensation were to be included in the Constitution, the Land Reform Act would also require amendment. Anderkopp was referring to Section $10^{31}$ of the Land Reform Act, which did refer to compensation, but postponed a concrete solution to the matter.

Jaan Teemant (1872-1941) of the Country People's Union then proposed that the words "for a just compensation" be added, because, while the Land Reform Act referenced a compensation, it never mentioned that the compensation ought to be

29 Vallikivi, H. Kodanikuõiguste ... [Civil rights ...], pp. 310-312.

30 Laaman, E. Kodaniku põhiõigused ja kohused [Civil rights and obligations]. In: Põhiseadus ja Rahvuskogu [Constitution and National Assembly]. Tallinn, 1937, p. 343.

31 "The specifics of the compensation paid for the aforementioned expropriated land and, if necessary, determining the size of the compensation and the types of land exempt from compensation will be solved in appropriate special legislation". 
just. He argued that this could lead to difficult consequences in the future and the expropriation of private property could only be allowed for a just compensation. This proposal was also rejected twice. ${ }^{32}$ In the Constitution, as it was ratified on 15 June $1920^{33}$, a section on the protection of private property did exist, but it did not mention a right to compensation for expropriated property. Despite the caution taken by Estonia's legislature, the former landowners soon questioned why their land was being taken away by a country whose Constitution's Section 24 explicitly stated the principle of private property rights: "Private property is protected for all citizens of Estonia." The same clause contained an exemption allowing privately owned land to be expropriated "only in the general interests of society in accordance with the law". The Land Reform Act was considered a law that sought to advance the greater good.

Ten years after the passing of the Land Reform Act, Ants Piip (1884-1942), a diplomat, professor of international law, politician and Labour Party assembly member said that from the perspective of international law, the greatest difficulty of the land reform was reconciling the reform with the efforts to gain support and recognition of Western European countries. Large-scale nationalisation of land was hardly going to increase the support for Estonia in countries that valued private property rights and remembered the actions of the Soviet regime in Russia. Hence, Estonian foreign delegations had to explain the preparations for the planned land reform to Western governments. Once the necessity of the reform had been explained on the basis of economic, social, and political reasons, it was no longer seen as a characteristically Bolshevik policy. ${ }^{34}$

\section{The Question on Compensation for Expropriated Land}

Although the Constitution did not place a requirement for compensation for expropriated property, and the Land Reform Act also left the matter unclear, the laws that were valid in Estonia at the time did mandate compensation. The main source of civil law was the codification of the private law of Russian Empire's Baltic provinces, the so-called Baltic Private Law Act. ${ }^{35}$ Its Article 868 (6) stated that private property could be expropriated without the owner's consent, provided the expropriation was necessary for the nation or the community, but the owner was to be compensated for the full value of the property before any such transfer of property took place. This was the basis for many lawsuits by former estate owners during the period of independence, some of which reached the Supreme Court of

32 Vallikivi, H. Põhiõiguste peatükk Eesti 1920. aasta põhiseaduses [Civil rights chapter in Estonia’s 1920 Constitution]. In: Riigiõiguse aastaraamat 2020 [Yearbook of Constitutional Law 2020] 2020, pp. 55-56.

33 Eesti Vabariigi põhiseadus [Constitution of the Republic of Estonia] (15.06.1920). State Gazette, No. 113/114, 1920, p. 243.

34 Piip, A. Maareform meie välispoliitikas [Land reform in our foreign policy]. Waba Maa, 25.10.1929, p. 6.

35 The third volume of Baltic Provincial Law Code (also known as the Estonian, Livonian and Courland Private Law or more commonly - as the Baltic Private Law Act), which was confirmed in 1864 and entered into force the following year, was at first applicable only for local nobility, town citizens, Lutheran clergymen and so-called literates. In the Republic of Estonia, with the law of abolition of estates (from 09.06.1920; State Gazette, No. 129/130, 1920, p. 54), its validity was expanded to all of the population of Estonia. Initially only the former Russian areas, which were united with Estonia according to the Tartu peace treaty (Petseri county and a strip of land east of the Narva River) were left out. 
Estonia. Several former estate owners claimed that as no compensation had been paid for their lands, even though such compensation was required according to the statutory Baltic Private Law, then no transfer of property had taken place. The Supreme Court dismissed their claims, arguing that the Land Reform Act was a special law in relation to the Baltic Private Law Act, therefore overriding the norm of compensation as described in general law. As such, the Land Reform Act was to take precedence. Even though the question of compensation had not been solved in a substantive and regulatory manner in the Land Reform Act, compensation had been explicitly mentioned. It was merely the specific details that had been postponed and were to be determined by additional legislation. This invalidated the claims that compensation was not regulated at all in the special law, which would have necessitated the application of Baltic Private Law as the general norm. ${ }^{36}$ Both the Supreme Court of Estonia, as well as the Secretariat and the Council of the League of Nations dismissed any lawsuits relating to matters of compensation. ${ }^{37}$

All the parties in the Constituent Assembly agreed that large-scale estates had to be liquidated with only the German party opposing it for obvious reasons. ${ }^{38}$ According to Section 1 of the Land Reform Act, not only the lands, but all of the agricultural inventory belonging to the estates was to be nationalised. Sections 11 and 12 specified compensations for livestock, as well as any other inventory. This did not cause disagreements in the Constituent Assembly. Compensation, or the lack thereof for expropriated land, on the other hand, was the cause of heated debate.

In the Committee on the Land Reform Act, arguments were presented in support and against compensation on political, economic, and legal grounds. Uluots was in favour of compensation, although he was mainly concerned about any reactions to the reform in Western Europe, if land were to be expropriated without any compensation whatsoever. He assumed that Estonia would have problems being accepted into the League of Nations, as all the other Eastern European countries, with an exception of Latvia and Russia, had paid compensation. ${ }^{39}$ The proposals for compensation were introduced to the Assembly by the People's Party and Uluots himself emphasized in the committee on 5 May 1919 that the matter needed to be decided so that Estonia could be accused of neither Bolshevism nor injustice. He argued that expropriation without compensation was unjust, and Estonia would likely come to regret the decision. ${ }^{40}$

36 E.g., the decision of the Civil Department of the Estonian Supreme Court of 20.11.1924, 1483. Rahvusarhiiv, ERA 1356.3.64, in which the complaint of the previous owner (Georg von Stackelberg) of the Roosna-Alliku Manor was solved. Stackelberg was able to use the land which was not redistributed during the reform up until 1939 (altogether 37.5 hectares). He was also allowed to use the first-floor premises of the manor. A school operated in other rooms of the manor: Roosna-Alliku mõisa ajalugu. Roosna-Alliku mõisa koduleht [History of the Roosna-Alliku Manor. Website of the Roosna-Alliku Manor]. Available: http://roosnaallikumois.ee/?c=ajalugu\&l=et [last viewed 11.04.2021].

37 More about the discussions about Estonian minorities and land question in the League of Nations see Made, V. Külalisena maailmapoliitikas. Eesti ja Rahvasteliit 1919-1946 [As a guest in the world politics. Estonia and the League of Nations]. Tartu, 1999, pp. 145-172.

38 Valge, J. Eesti parlament 1917-1940. Poliitiline ajalugu [Estonian Parliament 1917-1940. Political history]. Tallinn, 2019, pp. 153-171.

39 Maaseaduse komisjoni koosoleku protokoll [Minutes of the Land Reform Act Commission], No. 3 (05.05.1919). In: Asutava Kogu maaseaduse komisjoni protokollid [Minutes of the Land Reform Act Commission of the Constituent Assembly], 1919, 1920. Rahvusarhiiv, ERA.15.2.369, pp. 8-10.

40 Maaseaduse komisjoni koosoleku protokoll [Minutes of the Land Reform Act Commission], No. 2 (01.05.1919), No. 3 (05.05.1919), No. 13 (30.05.1919). In: Asutava Kogu maaseaduse komisjoni protokollid [Minutes of the Land Reform Act Commission of the Constituent Assembly], pp. 7-8, 26. 
Johan Jans (1880-1941), a lawyer and a Social Democratic assembly member was strongly opposed to compensation. Whilst he did not deny the right to private property per se, he did find that paying compensation for the estates could not be based on private property rights, as this property had been obtained illegally. Jans emphasized that he did not consider unpaid expropriation a revenge for historical injustice but rather a means of establishing a stable social order in accordance with the societal sense of justice. August Jürmann (1887-1942) of the Country People's Union opposed him, arguing that non-payment was actually a denial of property rights. Left-wing assembly members were not always in agreement either. When Jans mentioned unpaid expropriation as a national necessity, Johannes Zimmermann (1882-1942) of the Labour Party immediately responded, arguing that Jans' own arguments lead to the conclusion that abolition of private property altogether was necessary from the perspective of the state. ${ }^{41}$ Although the principal matter of compensation or a lack thereof was still undecided, the committee already started discussing actual evaluations to base the compensation on. ${ }^{42}$

The Landeswehr war had broken out by the time of the next committee meeting. Jans now said that he did not agree with compensation and the debates started all over again. ${ }^{43}$ By the time of the next meeting on 11 July the war was over. Although the Estonian victory did not necessarily seem decisive at the time, as only a ceasefire had been agreed upon in Riga on 3 July, Jans said, "Compensation cannot be discussed now, even if it could have been an option before the Landeswehr war. We will destroy unity at home if we pay compensation." Johannes Ernesaks (1876-1952), the other representative of the Social Democrats in the committee, seconded him. Anton Laar of the Christian People's Party argued that the best course of action was to wait and see what the reaction to unpaid compensation was abroad..$^{44}$ In the end, the committee decided to postpone any decisions on the matter of compensation. As a consequence, the Land Reform Act vaguely stated, "the matter of compensation for expropriated land will be solved by appropriate special legislation".

In 1920, when the Land Reform Act had been passed and the War of Independence was over, discussions over compensation continued in the Constituent Assembly. Although a draft of a statute on compensation for expropriated lands already existed, ${ }^{45}$ the committee continued to argue over whether to pay compensation at all. This time the discussions had a new nuance. According to the draft, compensation was not to be paid, but the state was to take liability for any debts

${ }_{41}$ Maaseaduse komisjoni koosoleku protokoll [Minutes of the Land Reform Act Commission], No. 13 (30.05.1919). In: Asutava Kogu maaseaduse komisjoni protokollid protokollid [Minutes of the Land Reform Act commission of the Constituent Assembly], p. 26.

42 Maaseaduse komisjoni koosoleku protokoll [Minutes of the Land Reform Act Commission], No. 15 (02.06.1919). In: Asutava Kogu maaseaduse komisjoni protokollid protokollid [Minutes of the Land Reform Act commission of the Constituent Assembly], pp. 28-30.

43 Maaseaduse komisjoni koosoleku protokoll [Minutes of the Land Reform Act Commission], No. 16 (18.06.1919). In: Asutava Kogu maaseaduse komisjoni protokollid protokollid [Minutes of the Land Reform Act commission of the Constituent Assembly], pp. 31-32.

44 Maaseaduse komisjoni koosoleku protokoll [Minutes of the Land Reform Act Commission], No. 27 (11.07.1919). In: Asutava Kogu maaseaduse komisjoni protokollid protokollid [Minutes of the Land Reform Act commission of the Constituent Assembly], p. 44.

45 Asutava Kogu maaseaduse komisjoni protokollid [Minutes of the Land Reform Act Commission of the Constituent Assembly], 1919, 1920. In: Asutava Kogu maaseaduse komisjoni protokollid [Minutes of the Land Reform Act commission of the Constituent Assembly], p. 102. 
on the expropriated properties. ${ }^{46}$ During a committee session on 11 June 1920, a draft titled "On paying compensation for lands expropriated according to the Land Reform Act" was discussed. The discussions in the committee referred to the Land Reform Act itself, finding that paying compensation was inevitable, because doing the opposite would have required amending the Land Reform Act and contradicted the principle of private property rights. Strandman pointed out that Section 1 of the Land Reform Act already determined the payment of compensation and the new draft under discussion was only meant to specify the conditions and size of compensation. Giving up compensation entirely would have required amending the Land Reform Act. ${ }^{47}$ Despite that, Section 1 of the draft said: "compensation shall not be paid for expropriated land". Section 2, on the other hand, stated: "Any debts engrossed on the expropriated lands will be the liability of the Republic of Estonia". ${ }^{48}$ The full Assembly debated the draft further on 29 June 1920. Jans proposed moving the draft forward to the first reading, because uncertainty over debts of the former estates and compensation was beginning to delay the reform itself. ${ }^{49}$ The Ministry of Agriculture also requested that the draft should move forward. ${ }^{50}$ Thus started the first reading of the draft. Strandman argued that the draft should be sent to the Committee on Finance, as no proposal was likely to receive the support of a majority in the Committee on the Land Reform Act and the same result could be expected in the full Assembly. ${ }^{51}$ Theodor Pool pointed out that the draft, as introduced by the committee, was diametrically contradictory to the government's draft: the committee decided to expropriate the lands without compensation, whereas the government's plan included compensation. He also found that the committee should have supported compensation if it also supported the state taking liability for debts. ${ }^{52}$

Hugo Kuusner (1887-1942), an attorney and a member of the People's Party declared that their party did not support the draft but would support sending it to the Committee on Finance. The Christian People's Party took the same position and although Rudolf von Stackelberg (1872-1934) of the Baltic German Party proposed rejecting the draft altogether, the majority of the assembly voted for sending the draft to the Committee on Finance. ${ }^{53}$ In the end, the Constituent Assembly left the matter of compensation undecided.

As there was no clear legal order, contemporary legal scholars and jurists presented contradictory opinions on the matter. Eduard Berendts, (1860-1930),

46 The first reading of the draft which was developed by the Ministry of Agriculture was conducted on 09.06.1920 at the meeting of the Land Reform Act Committee. By the end of the meeting, the draft was agreed to be adopted and submitted to the second reading: Maaseaduse komisjoni koosoleku protokoll [Minutes of the Land Reform Act Commission], No. 7 (09.06.1920). In: Asutava Kogu maaseaduse komisjoni protokollid [Minutes of the Land Reform Act Commission of the Constituent Assembly], p. 90.

47 Maaseaduse komisjoni koosoleku protokoll [Minutes of the Land Reform Act Commission], No. 8 (11.06.1920). In: Asutava Kogu maaseaduse komisjoni protokollid [Minutes of the Land Reform Act commission of the Constituent Assembly], p. 96.

48 Asutava Kogu maaseaduse komisjoni protokollid [Minutes of the Land Reform Act Commission of the Constituent Assembly], p. 101.

49 Asutawa Kogu protokoll [Minutes of the Constituent Assembly], No. 145 (29.06.1920). In: Asutawa Kogu IV istungjärk: protokollid [IV session of the Constituent Assembly. Minutes], No. 120-154 (13.04-31.12.1920). Tallinn, 1920, col. 1188.

50 Ibid.

51 Ibid., col. 1199.

52 Ibid., col. 1200.

53 Ibid., col. 1207. 
a professor of financial law at the University of Tartu, claimed that expropriation without compensation was unconstitutional, emphasizing primarily the preamble and the spirit of the constitution. Only thereafter did he equate expropriation without compensation with violations of constitutionally granted equality before law and private property rights. ${ }^{54}$ Eugen Maddison (1886-1954), an official of the Ministry of Internal Affairs, disagreed with Berendts. ${ }^{55}$ To Berendts' argument that expropriating land without compensation ("confiscating private property") was in conflict with "justice" as mentioned in the preamble, Maddison responded that unjust would be a situation wherein the state would need to expropriate the property of a certain social stratum and to maintain the supposed justice the state should not "rob the people blind with taxes". Berendts had also pointed to Section 4 of the Constitution, which mentioned generally recognised norms of international law as a part of the Estonian legal order. As the constitutions of other countries required just compensation for expropriation, this should be considered as a norm of international law. Maddison responded that such norms were not a part of international law and were the rules of each sovereign state. Thirdly, Berendts referred to Section 6 of the Constitution (equality before law), saying that expropriation did not concern formal titles of societal class which had been abolished, but rather land owners as a social class. As large-scale land owners were also members of the land-owning class, Berendts argued that they should be constitutionally protected from unequal treatment. Maddison, on the other hand, claimed that Section 6 could not be interpreted as meaning social class, but rather as just abolishing existing privileges and titles which could only have been restored by amending the Constitution. The fourth justification Berendts provided was the principle of private property protection as outlined in Section 24 of the Constitution. According to Berendts, the Section did not explicitly mention compensation because the preamble and the spirit of the Constitution (justice, legality, liberty) meant that compensation was to be taken for granted. Maddison thought that compensation was deliberately excluded from the Constitution. Section 24 solely specified that expropriation could take place only in the general interest (consequently, not on someone's personal whim), in accordance with the law (thus, not administratively), and in a manner specified by the law (not according to the plans of the executive branch). How the expropriation was to take place (with or without compensation) was to be decided by special laws in every individual case. Therefore, if compensation was intended to be a necessary condition of expropriation, this would have been explicitly stated in the Constitution.

The Berendts-Maddison debate took place against the backdrop of a draft introduced to the Parliament by the Social Democratic Workers' Party in 1924, which would have legalised expropriation of lands without compensation. By contrast, in 1925 the Baltic German Party introduced a draft that would have mandated compensation to a relatively large extent. The Committee on the Land Reform Act instead based its decisions on the government's draft that specified compensation in 60-year governmental bonds. ${ }^{56}$

54 Berendts, E. Die Verfassungsentwicklung Estlands. Tübingen, 1924, S. 194.

55 Maddison, E. Kas lubab põhiseadus mõisat tasuta võorandada [Does the Constitution allow to expropriate a manor without any compensation]? Waba Maa, 29.05.1924, p. 2.

56 While the parliamentary discussions were still ongoing, Johan Jans, who participated actively already in the Constituent Assembly, published several critical writings about this topic: Jans, J. Kas oleme kohustatud võõrandatud mõisate eest tasu maksma [Are we obliged to pay compensation for expropriated land]? Tallinn, 1926; Jans, J. Maaseadusega võõrandatud maade eest tasu maksmise 
Eventually, the question of compensation was settled in the manner proposed by the Government and in 1926 the II Parliament passed the corresponding statute..$^{57}$ The Social Democrats proposed holding a referendum on the Compensation Act on 5 March 1926. If their proposal had received majority support in the Parliament, the people may well have voted against paying compensation. The III Parliament was elected in May 1926 and the Social Democrats, inspired by their electoral success, proposed a draft for referendum on 10 August 1926 which would have legalised not paying compensation. On 25 October of the same year, a demand for a referendum with 500 signatures was presented to the Parliament. In accordance with Section 15 of the Constitution, arrangements for a referendum began. The Parliament declared another round of signature collection, which ended on 23 December with 76450 valid signatures. ${ }^{58}$ According to Section 32 of the Constitution, this meant the dissolution of the Parliament and new elections.

The Board of the Parliament, however, started a new debate. The so-called bourgeoisie parties argued that the expropriation of lands under the Land Reform Act can be considered as legislation on taxation and according to Section 34 of the Constitution, legislation regarding taxation was not to be subject to referenda. The tax legislation argument had been introduced to the legal discussion by the aforementioned professor Berendts. He regarded expropriation of land without compensation as taxation of a certain amount of property, making it exempt from referenda. ${ }^{59}$ Kaarel Parts, Chief Justice of the Supreme Court, did not agree with Berendts. He said that the relevant arguments originated from the state socialist economist Adolph Wagner (1835-1917) who thought that expropriation of land for societal purposes was included in the definition of taxation. Parts claimed that the Land Reform Act had different aims than a tax law, and any decisions ought to be based on the statutory order and the will of the legislator, and not arise from competing scientific theories. If the Land Reform Act and Compensation Act could be counted as tax laws, then so could any laws that had an effect on the state budget be considered as tax legislation. ${ }^{60}$ This was Parts' dissenting opinion, which he published in a legal journal after the Board of the Parliament had concluded, after a consultation with legal experts on 7 February 1927, that the Land Reform Act was an act of legislation on taxation and therefore as exempt from being voted on in a referendum. The professors Uluots and Piip were also present at the consultation in addition to Parts. Referencing the expert opinion, the board ruled with three votes to two that the draft of Social Democrats was legislation on taxation, deciding not to present it to the Parliament for confirmation. ${ }^{61}$ Artur Mägi (1904-1981), then a law student at the University of Tartu and later a university teacher, the secretary general of the elections to the National Assembly and the VI Parliament, the Secretary of State and the Chancellor of Justice of the Estonian government in exile and one of the most important scholars of constitutional law in Estonia later

küsimus [The question about compensation for lands expropriated with the Land Reform Act]. Õigus, No. 1, 1926, pp. 1-9, No. 2, pp. 33-41.

57 Riikliku maatagavara loomiseks võorandatud maade eest tasumaksmise seadus [Law on paying fee for expropriated land which was created for national land reserve] (05.03.1926). State Gazette, No. 26, 1926.

58 Uuet, L. Ärajäänud rahvahääletus [The cancelled referendum]. Postimees, 30.01.2021, pp. 6-7.

59 Berendts, E. Die Verfassungsentwicklung Estlands, p. 201.

60 Parts, K. Mis on "maksuseaduste" all Põhiseaduse $\$ 34$ mõeldud [What is meant with "tax laws" in article 34 of the Constitution]? Õigus, No. 1, 1927, pp. 6-10.

61 Uuet, L. Ärajäänud rahvahäletus [The cancelled referendum], p. 7. 
claimed: "It is clear that the course of action taken by the Board of Parliament was unconstitutional. The Board had already given permission to the Social Democrats to present their draft and had declared it constitutional. A different opinion by a panel of experts did not justify a change of the decision by the Board, particularly as such a privately expressed opinion had no binding authority. Section 34 of the Constitution also contained a specific list of matters that could not be decided by a referendum." The Parliament and its Board in particular had no authority to extend this list "by means of interpretation". 62

In 1927, though, life and legal practice went on as if the decision of the Board of Parliament had been constitutional. In accordance with the Compensation Act of 5 March 1926, committees were formed and payments of compensation for expropriated land started, albeit, in the opinion of the former estate owners, in a manner too slow and shamefully stingy. Perhaps the fact that even some kind of a solution could be found for the question of compensation was the reason why the second Constitution of the Republic of Estonia, passed in 1937 included a clause on the protection of private property with all its elements as had already been proposed by Uluots for the Constitution of 1920: "Article 26. The right to property is protected. Any restrictions to those rights shall be determined by relevant legislation. Expropriation of private property without the consent of the owner can only take place in accordance with the law in the general interest and for a just compensation. The right to settle the matter in court is ensured for any disputes."

\section{Summary}

The early years of the land reform were marked by the expropriation of largescale land holdings and the creation of a national land reserve. Although it formed the basis of the land reform, it was not by far limited to that. In order to execute the land reform, far wider legal basis was necessary. The redistribution of the lands followed and, in some cases, also returning of these lands. Redistribution was not possible without exact planning of the land which was not an easy task, considering the large amount of distributed land and the great numbers of eligible beneficiaries. All this required a lot of further laws, decrees and ordinances, which could not be reviewed in the current paper. Here we could only present the very first decisions and legal solutions concerning the Estonian land reform, as well as their backgrounds. In terms of their significance, however, both the expropriation of the lands and the question of compensation for these lands have been fundamental in their nature and have shaped the image of land reform in Estonia, especially outside the country to a greater extent than all the other stages of the same reform.

\section{Sources}

\section{Bibliography}

1. Berendts, E. Die Verfassungsentwicklung Estlands. Tübingen, 1924.

2. Bernmann, O. Die Agrarfrage in Estland. Berlin, 1920.

3. Einbund, K. Öiguslik riik [The Rule of Law]. Tartu, 1918.

4. Jans, J. Kas oleme kohustatud võõrandatud mõisate eest tasu maksma [Are we obliged to pay compensation for expropriated land]? Tallinn, 1926.

$\overline{62}$ Mägi, A. Rahvahääletus ja rahvaalgatus Eestis [Referendum and popular initiative in Estonia]. In: Omariikluse taustal ... [In the context of independence ...], p. 22. 
5. Jans, J. Maaseadusega võorandatud maade eest tasu maksmise küsimus [The question about compensation for lands expropriated with the Land Reform Act]. Õigus, No. 1, 1926, pp. 1-9, No. 2, pp. 33-41.

6. Jörgensen, $H$. The Inter-War Land Reforms in Estonia, Finland and Bulgaria: a Comparative Study. Scandinavian Economic History Review, Vol. 54, Issue 1, 2006.

7. Kalmo, H., Luts-Sootak, M. Eesti riik kui kunstiteos [Estonian state as a piece of art]. Sirp, 06.09.2019.

8. Karelson, M. Theodor Pool Eesti Vabariigi põllumajanduses [Theodor Pool in the agriculture of the Republic of Estonia]. Tartu, 2000.

9. Karelson, M. Theodor Pool - maaseadus ja maareform [Theodor Pool - the Land Reform Act and land reform]. In: Agraarteadus (Akadeemilise Põllumajanduse Seltsi Toimetused 13) [Agrarian Science (Publications of the Academic Aricultural Society 13)]. Tartu, 2000, pp. 10-15.

10. Karlson, F. Õigusteaduse oskussõnad [Terms of law]. Õigus, No. 1, 1920.

11. Keyserling, H. von. Esthonia's Future - The Land Question. The Daily Telegraph, 17.09.1919.

12. Korfes, O. Die Agrarrevolutionen in Estland und Lettland. In: Sering, M. (Hg.). Die agrarischen Umwälzungen im außerrussischen Osteuropa. Berlin, Lepizig 1930, S. 72-127.

13. Krauss, K. P. (Hg.). Agrarreformen und ethnodemographische Veränderungen. Südosteuropa vom ausgehenden 18. Jh. bis in die Gegenwart. Stuttgart, 2009.

14. Kuldkepp, $M$. Rahvusliku enesemääramise kaudu Saksamaa külge: eestlased anneksionistliku Saksa poliitika sihtmärgina 1918. aasta okupatsiooni eel [Unification with Germany through national self-determination: Estonians as a target of annexionist German policy before the 1918 German occupation]. In: Tannberg, T. (ed.). Esimene maailmasõda ja Eesti. II [WWI and Estonia. II]. Tartu, 2016, pp. 369-433.

15. Kõll, A.-M. The Agrarian Question in Eastern Europe: Some Answers from the Baltic Region. In: David, T., Batou, J. (eds.). Uneven Development in Europe 1918-1939. Librarie Droz, 1999, pp. 201-229.

16. Laaman, E. Isik ja riik Eesti põhiseadustes [Person and state in Estonian constitutions]. Õigus, No. 3, 1937.

17. Laaman, E. Kodaniku põhiõigused ja kohused [Civil rights and obligations]. In: Põhiseadus ja Rahvuskogu [Constitution and National Assembly]. Tallinn, 1937, p. 343.

18. Laur, M., Lust, K., Pirsko, P., Tarkiainen, Ü. Talude päriseksostmine Pärnumaa andmestiku põhjal [The purchasing of farmsteads on the basis of data from Pärnumaa]. Tartu, 2014, pp. 9-14.

19. Leminkainen, $Y$. [= Hermann von Keyserling]. Die Politische Bedeutung von Estland: Das Verhältnis zum Bolschewismus. Neue Freie Presse (Wien), 08.01.1921.

20. Lipping, I. Land Reform Legislation in Estonia and the Disestablishment of the Baltic German Rural Elite 1919-1930. Dissertation, University of Maryland Faculty oh the Graduate School. Michigan, London, 1980.

21. Loit, A. Baltisaksa rüütelkondade seisukohad ja tegevus Eesti iseseisvumisel 1918-1920 [The views and activity of the Baltic German knighthood at the independence of Estonia 1918-1920]. Tuna, No. 4, 2006, pp. 60-68.

22. Luiga, G. E. Die Agrarreform in Eesti. Helsinki, 1920.

23. Maddison, E. Kas lubab põhiseadus mõisat tasuta võõrandada [Does the Constitution allow to expropriate a manor without any compensation]? Waba Maa, 29.05.1924.

24. Made, V. Külalisena maailmapoliitikas. Eesti ja Rahvasteliit 1919-1946 [As a guest in the world politics. Estonia and the League of Nations]. Tartu, 1999.

25. Mertelsmann, M., Mertelsmann, O. Landreform in Estland 1919. Die Reaktionen von Esten und Deutschbalten. Hamburg, 2012, S. 47-68.

26. Mägi, A. Rahvahääletus ja rahvaalgatus Eestis [Referendum and popular initiative in Estonia]. In: Omariikluse taustal. Üliõpilasselts Raimla koguteos [In the context of independence. Collected works by Student Society Raimla]. Uppsala, 1955.

27. Nõu, J. Eesti põllumajanduse omariiklusaegne koetus ja arengutase [The structure and level of development of Estonian agriculture during the period of independence]. In: Omariikluse taustal. Üliõpilasselts Raimla koguteos [In the context of independence. Collected works by Student Society Raimla]. Uppsala, 1955, pp. 59-70.

28. Parts, K. Mis on "maksuseaduste" all Põhiseaduse $\$ 34$ mõeldud [What is meant with "tax laws" in article 34 of the Constitution]? Õigus, No. 1, 1927.

29. Piip, A. Maareform meie välispoliitikas [Land reform in our foreign policy]. Waba Maa, 25.10.1929.

30. Pilve, E. Millele nad lootsid?: Eesti Rahvaerakonna ja Eesti Maarahva Liidu maailmapoliitika ning selle kujunemine 1919. aasta maaseaduse eel [What they hoped for?: World politics of the Estonian People's party and Estonians Country People's Union]. Akadeemia, No. 2, 2017, pp. 239-259. 
31. Pilve, E. Millele nad lootsid?: Eesti Rahvaerakonna ja Eesti Maarahva Liidu maailmapoliitika ning selle kujunemine 1919. aasta maaseaduse eel [What they hoped for?: World politics of the Estonian People's party and Estonians Country People's Union]. Akadeemia, No. 3, 2017, pp. 413-442.

32. Pool, T. Maauuendus Eestis ja selle tulemusi [Land reform in Estonia and its results]. In: FennoUgrica V. Soome-ugri kultuurkongress (ettekanded) [Finno-Ugric cultural congress (lectures)]. Tallinn, 1936, pp. 4-8.

33. Roasto, M. Konstantin Pätsi "maaküsimus" ja selle ajalooline kontekst [The "land question" of Konstantin Päts and its historical context]. Ajalooline ajakiri / The Estonian Historical Journal, No. 4, 2014, pp. 303-328.

34. Roasto, $M$. The political debate about the land question in the Estonian area of the Baltic provinces, 1905-1914. Journal of Baltic Studies, No. 51(4), 2020, pp. 611-630.

35. Roosna-Alliku mõisa ajalugu. Roosna-Alliku mõisa koduleht [History of the Roosna-Alliku manor. Website of the Roosna-Alliku manor]. Available: http://roosnaallikumois.ee/?c=ajalugu\&l=et [last viewed 11.04.2021].

36. Rosenberg, T. Eesti 1919. aasta maareformi historiograafia [Historiography of the Estonian land reform of 1919]. In: Rosenberg, T. Künnivaod. Uurimusi Eesti 18.-20. sajandi agraarajaloost [Ploughed fields. Inquiries on the agrarian history of Estonia in the $18^{\text {th }}$ to $20^{\text {th }}$ century]. Tartu, 2013.

37. Rosenberg, T. Maaküsimus ja 1919. aasta maareform Eestis: põhjused, eeldused ja tulemused [The land question and the land reform of 1919 in Estonia: reasons, preconditions and results]. In: Rosenberg, T. Künnivaod. Uurimusi Eesti 18.-20. sajandi agraarajaloost [Ploughed fields. Inquiries on the agrarian history of Estonia in the $18^{\text {th }}$ to $20^{\text {th }}$ century]. Tartu, 2013.

38. Roszkowski, W. Land Reforms in East Central Europe after World War One. Warsaw, 1995.

39. Uluots, J. Grundzüge der Agrargeschichte Estlands. Tartu, 1935.

40. Undusk, J. Eesti kui Belgia. Viimane baltlane Hermann Keyserling [Estonia like Belgium. The last Baltic Hermann Keyserling]. Tuna, No. 2, 2003, pp. 59-89.

41. Uuet, L. Ärajäänud rahvahääletus [The cancelled referendum]. Postimees, 30.01.2021.

42. Valge, J. Eesti parlament 1917-1940. Poliitiline ajalugu [Estonian Parliament 1917-1940. Political history]. Tallinn, 2019.

43. Vallikivi, H. Kodanikuõiguste peatükk Eesti 1919. aasta ajutises põhiseaduses [Civil rights chapter in Estonia's 1919 Preliminary Constitution]. Ajalooline Ajakiri / The Estonian Historical Journal, No. 3/4, 2019, pp. 294-295.

44. Vallikivi, H. Põhiõiguste peatükk Eesti 1920. aasta põhiseaduses [Civil rights chapter in Estonia’s 1920 Constitution]. In: Riigiõiguse aastaraamat 2020 [Yearbook of Constitutional Law 2020], p. $55-56$.

45. Virma, F. Maasuhted ja maakorraldus Eestis [Land relations and land arrangement in Estonia]. Tartu, 2004.

\section{Normative Acts}

1. Manifest Eestimaa rahvastele [Manifesto to the Peoples of Estonia] (24.02.1918). State Gazette, No. $1,1918$.

2. Ajutise Valitsuse määrus [Decree of the Provisional Government] (20.12.1918). State Gazette, No. 9 , 1918.

3. Eesti vabariigi valitsemise ajutine kord [Provisional Regulation on the Government of the Republic of Estonia]. State Gazette, No. 44, 1919.

4. Maaseadus [Land Reform Act] (10.10.1919). State Gazette, No. 79/80, 1919.

5. Eesti Vabariigi põhiseadus [Constitution of the Republic of Estonia] (15.06.1920). State Gazette, No. 113/114, 1920.

6. Riikliku maatagavara loomiseks võõrandatud maade eest tasumaksmise seadus [Law on paying fee for expropriated land which was created for national land reserve] (05.03.1926). State Gazette, No. $26,1926$.

\section{Other Sources}

1. Asutawa Kogu protokoll 29.07.1919 [Minutes of the Constituent Assembly 27 July 1919], No. 40. In: Asutawa Kogu II istungjärk: protokollid nr 28-97 (17. juuni - 20. dets. 1919. a) [II session of the Constituent Assembly: minutes No. 28-97 (17 June 1919 - 20 December 1919)]. Tallinn, 1920.

2. Asutawa Kogu protokoll 01.08.1919 [Minutes of the Constituent Assembly 1 August 1919], No. 41. Asutawa Kogu II istungjärk: protokollid nr 28-97 (17. juuni - 20. dets. 1919. a) [II session of the Constituent Assembly: minutes No. 28-97 (17 June 1919 - 20 December 1919)]. Tallinn, 1920. 
3. Asutawa Kogu protokoll [Minutes of the Constituent Assembly], No. 145 (29.06.1920). In: Asutawa Kogu IV istungjärk: protokollid [IV session of the Constituent Assembly. Minutes], No. 120-154 (13.04-31.12.1920). Tallinn, 1920.

4. Maaseaduse komisjoni koosoleku protokoll 01.05.1919, [Minutes of the Land Reform Act commission of the Constituent Assembly 1 May 1919], No. 2. Rahvusarhiiv [Estonian National Archive], ERA.15.2.370.

5. Maaseaduse komisjoni koosoleku protokoll [Minute of the Land Reform Act commission], No. 3 (05.05.1919). In: Asutava Kogu maaseaduse komisjoni protokollid [Minutes of the Land Reform Act commission of the Constituent Assembly], 1919, 1920. Rahvusarhiiv, ERA.15.2.369.

6. Maaseaduse komisjoni koosoleku protokoll [Minute of the Land Reform Act commission], No. 7 (09.06.1920). In: Asutava Kogu maaseaduse komisjoni protokollid [Minutes of the Land Reform Act commission of the Constituent Assembly], 1919, 1920. Rahvusarhiiv, ERA.15.2.369.

7. Maaseaduse komisjoni koosoleku protokoll [Minute of the Land Reform Act commission], No. 8 (11.06.1920). In: Asutava Kogu maaseaduse komisjoni protokollid [Minutes of the Land Reform Act commission of the Constituent Assembly], 1919, 1920. Rahvusarhiiv, ERA.15.2.369.

8. Maaseaduse komisjoni koosoleku protokoll [Minute of the Land Reform Act commission], No. 13 (30.05.1919). In: Asutava Kogu maaseaduse komisjoni protokollid [Minutes of the Land Reform Act commission of the Constituent Assembly], 1919, 1920. Rahvusarhiiv, ERA.15.2.369.

9. Maaseaduse komisjoni koosoleku protokoll [Minute of the Land Reform Act commission], No. 15 (02.06.1919). In: Asutava Kogu maaseaduse komisjoni protokollid [Minutes of the Land Reform Act commission of the Constituent Assembly], 1919, 1920. Rahvusarhiiv, ERA.15.2.369.

10. Maaseaduse komisjoni koosoleku protokoll [Minute of the Land Reform Act commission], No. 16 (18.06.1919). In: Asutava Kogu maaseaduse komisjoni protokollid [Minutes of the Land Reform Act commission of the Constituent Assembly], 1919, 1920. Rahvusarhiiv, ERA.15.2.369.

11. Maaseaduse komisjoni koosoleku protokoll [Minute of the Land Reform Act commission], No. 27 (11.07.1919). In: Asutava Kogu maaseaduse komisjoni protokollid [Minutes of the Land Reform Act commission of the Constituent Assembly], 1919, 1920. Rahvusarhiiv, ERA.15.2.369. 